\title{
Empirical study of the comfort of living and working environment - Ukraine and Europe: comparative assessment
}

\author{
Halyna Mishchuk \\ National University of Water Management and Nature Resources Use \\ Ukraine \\ mischuk_galina@ukr.net
}

\author{
Olena Grishnova \\ Taras Shevchenko Kyiv National University \\ Ukraine \\ grishnova@ukr.net
}

Abstract. This paper reports findings from a comparative assessment of the "comfort" and "well-being" concepts which are used in socio-economic research to evaluate the living and working environment of the population. The use of indicators of material, social, and psychological needs satisfaction has become important as useful methodologies for the characterisation, evaluation and diagnostic of comfort. The assessment is based on the available statistical data of Ukraine and some European countries. The authors found a significant impact of a number of economic and non-economic factors on

Received: 1st Revision: February, 2015

Accepted: May, 2015 the external migration of the population (the result of the discomfort of living in their country). The most significant external migration factors are: health care needs and conditions for the for life extension, protection of human rights, need to ensure the material component of a comfortable life and satisfaction with the standard of living. The authors recommend using such approach in the economic-mathematical modelling for the purpose of state socio-economic control. The key actions aiming to comfortable life protection are improving health, creating conditions, providing the material component of a comfortable life (personal income), and advocating for the compliance with civil rights.

Keywords: well-being, living and working environment, EU, Ukraine

JEL Classification: I31, I32, P36

\section{INTRODUCTION}

The need for comfortable living conditions in the country is a fundamental prerequisite for sustainable development. Interestingly, an analysis of migration attracts the attention of researchers working in different subject areas: economics of sustainable development, human development, and social economics. Despite the differences in methodology and methodological research principles the investigations have one thing in 
common: all of them recognize and search for social causes of individual economic decisions. In this regard, the value of investigating environment comfort factors becomes particularly important. Unfortunately, this issue hasn't been highlighted and recognized in the works of Ukrainian scientists so far.

Furthermore, supporting and improving the comfort of living environment, including the workplace, has recently become more important. The growing significance of the well-being of humans and raised standard of living is revealed through the increase of applied scientific research with the focus on basic aspects of a comfortable life: justice, social responsibility, development of social interaction and competency on the basis of fair and open competition. Such studies become more and more common, and the main components of comfort are the subject to special statistical and sociological assessments. This situation is predominantly true for the countries in which the idea of a social state is highly valued, primarily for the UK and Canada.

While recognizing the importance of providing a comfortable life which is demonstrated in the related economy studies to varying extend, social comfort is one of the latest socio-economic concepts and currently it is at the stage of formation. This term is rarely used in the domestic economy; it refers primarily to the interests of sociologists. There are special surveys and investigations well-known in this regard, in particular those include "happiness factors" (Happy Planet Index) and list of the world's best countries which actually ranks countries based on the comfort of certain environment components.

Nonetheless, some studies are very good in theoretical and/or methodological aspect. However, the greatest challenge to the theorists is the organization of all hypothetically relevant comfort factors (most of them are social, often political in nature and origin) into one coherent theoretical framework that will specify their interaction with economic consequences for society in empirically testable form and thereby serve as a guide to future research. If we consider the enterprise level, the impact of discomfort factors on the working environment is clearly associated with economic consequences in the logical chain "discomfort - staff turnover - performance loss". In this case it is used to react on the comfort changes by means of motivation. At the societal level the connection between discomfort and its economic consequences for the entire country, as well as the state's economic prospects, is even more important. The lack of response to negative change is more tangible on the national level, too. Besides, as of today, the majority of scientists explain individual decisions about long-term, including irreversible migration (the fluidity of a population indicator transformed for macroeconomic level) primarily by the dissatisfaction with material components of comfort in their native country.

Given this, our article is devoted to the development of new tools assessing the influence of comfort determinants on the emigration decision advocating that migration is an investment in one's well-being and the emigration demonstrates the people's dissatisfaction with the existing living and working environment in their country.

\section{HYPOTHESES}

1. External migration of the population doesn't depend solely upon the material constituents of comfort. The impact of social factors, i.e. justice, civil rights, the rule of law in the country, opportunities to maintain health, is significant. The role of factors that characterize the opportunities people have to realize their true potential and an environment that allows everyone to go beyond his or her limitations (the overall level of innovation, the use of knowledge in the economy etc.) is also substantial. 
2. The influence of the comfort factors (both social and economic ones) can be formalized in the form of economic-mathematical model suitable to control the components of comfortable environment that can make people stay and work in their country aiming to prevent excessive external migration.

\section{LITERATURE REVIEW}

Foreign researchers tend to avoid using the concept of "comfort" in order to examine the relationship of social and economic factors. On the contrary, research on well-being which is essentially similar to comforts consistently reveals that the characteristics and resources valued by society correlate with happiness. Thus, the Oxford Dictionary defines well-being as "the state of being comfortable, healthy, or happy" (Oxford Dictionary). Another recognized explanatory dictionary of contemporary English, the Longman Dictionary, repeats this definition almost word for word, i.e. "a feeling of being comfortable, healthy, and happy" (The Longman Dictionary, 1992, p.1196). Therefore, such a substantial characteristic is one of the most simple and at the same time comprehensive definitions. That is why, it is still used not only in speech, but it also provides the methodological basis for the study of some of the key factors of the state of well-being. In particular, this definition was taken into account in the monitoring system elaborated by the World Health Organization experts on targets and indicators for health and well-being in regard to healthy lifestyle (WHO, 2012, p.4).

Despite the fact that there is a certain identification of concepts ("comfort", "happiness") which are separate research fields, the detailed analysis of the "well-being" essence allows us to come to the conclusion that nowadays foreign economists view comfort / well-being as a feeling of needs' satisfaction. Accordingly, they assess the concept basing on the components of the social environment.

There are key concepts which have been dominant for a long time and were based on psychological sensations. Those researches have actually defined the modern trends and the components of the assessment of well-being. Indeed, in John Rawls' perception, well-being depends upon "a scheme of cooperation without which no one could have a satisfactory life" (John Bordley Rawls, 1971); in Max-Neef's theory, well-being model helps to determine the satisfiers required for fulfilment of the needs of a specific group or society (Manfred Max Neef, 1992). More recent formulations of preference satisfaction require that preferences are informed in the sense that they are based on the considered use of all relevant information and some accounts exclude certain 'anti-social' preferences (John Charles Harsanyi, 1996), such as those related to envy, even when they are informed (Dolan, P., Peasgood, T., White, M., 2006, p.15). Such associations between subjective evaluations of well-being and psychological factors led most investigators to assume that the satisfaction of mental needs significantly improves people's welfare. For example, Ryan and Deci's self-determination theory (Ryan and Deci, 2000) posits three basic psychological needs (autonomy, competence and relatedness) which are necessary for individual well-being (Dolan, P., Peasgood, T., White, M., 2006, p.15).

Since the first theoretical basis for the well-being had appeared, such social and economic research received international recognition. Today, the factors of well-being are increasingly important in explaining economic actions and outcomes, both at the macro and individual level. They become interdisciplinary in their nature and are used as an alternative tool (separate or additional) for assessing the quality of state social sphere management.

In this context, the importance of various elements in evaluating well-being and freedom of people can be adequately appreciated and assessed. In the latest Human Development Report, UNDP committed itself to explore the use of subjective indicators of well-being in a separate table of indicators called "Social integration". These indicators - appropriately measured and carefully used - are presented as a set of esti- 
mates divided into four blocks: employment, vulnerability and equity; perceptions of individual well-being; perceptions of society; and human safety (UNDP, 2013, p.174).

The Happy Planet Index, one of the most popular and respected indicators in scientific community, was founded in 2006 by an independent British think-and-do tank called the New Economic Foundation (NEF). It is significant that even though the index is called the Happy Planet Index, it measures what matters: the extent to which countries deliver long, happy, sustainable lives for the people that live in them. The Index uses global data on life expectancy, experienced well-being and Ecological Footprint to calculate this. The Centre for Well-being at NEF, responsible for the HPI calculation, seeks to understand, measure and influence well-being.

Another example in this regard would be a new "quality of life" index developed by the Economist Intelligence Unit. It is based on a unique methodology that links the results of subjective life-satisfaction surveys to the objective determinants of quality of life across countries. The index has been first calculated in 2005. Due to the fact that the conceptual basis of the index includes much broader concepts (quality of life), in the overall assessment there are nine quality-of-life factors, and the indicators used to represent these factors. Those are: material wellbeing, health, political stability and security, family life, community life, climate and geography, job security, political freedom, and gender equality. Apart from family life, climate and geography other seven components of the index very closely correspond to the other methods of the well-being research.

The 2014 Legatum Prosperity Index ${ }^{\mathrm{TM}}$ demonstrates greater frequency and prevalence. In 2006 the first Prosperity Index was published by the Legatum Institute, a charitable public policy think-tank whose mission is "to help people lead more prosperous lives". Its Legatum Prosperity Index ${ }^{\mathrm{TM}}$ assesses a wide range of indicators including both common objects of well-being assessment (economics, entrepreneurship, management, education, health, security, personal freedom), and a new indicator of comfort and interaction in society - social capital. As for social capital, the official website of the Legatum Institute provides the basic principle "Prosperity is more than just the accumulation of material wealth. It is also the joy of everyday life and the prospect of being able to build an even better life in the future" (The Legatum Prosperity Index, 2014).

In these methods, the factors of comfort/well-being are directly or indirectly included in the index which characterizes the satisfaction of individual needs - freedom, prosperity, security, health, etc. - according to the approach of different analytical organizations. Their common basis is the recognition of the adequacy of the subjective assessment of satisfaction of the majority of needs. Only specific factors (e.g. average life expectancy as an integral indicator of the state management in health protection, GDP per capita as a factor in material well-being, some other indicators) are subjects to rating on the basis of their statistical variables. At the same time, the above methods reveal considerable variation of individual estimates due to the different purposes of research: a set of indicators for the evaluation of the corresponding components of the socio-economic sphere considered to be the most significant ones from the point of view of researchers.

Agreeing to the fact that each of the methodological aspects of the research on people's well-being has certain advantages, at the same time we believe there is a need to use more precise definitions of comfort / well-being in the analysis of the socio-labour field. This will allow delineating the factors more clearly and summarizing the outcomes of comport factors' impact.

In order to conduct the relevant study one can use two specialized researches which are pioneering in the field of direct prosperity assessment so far. The first study produced by Canadian experts resulted in the Canadian Index of wellbeing (CIW), a composite index, composed of eight interconnected domains that measures stability and change in the well-being of Canadians over time. Other atypical example of well-being assessment is the method offered by British scientists in 2006. It considers how people's health and well-being can be defined, measured and improved in ways that help UK policy-makers determine the 
best use of scarce resources, and to investigate the determinants of well-being insofar as these are relevant to policy formulation (Centre for Well-being in Public Policy, University of Sheffield). The focus of the British assessment methodology, however, is largely on measures of personal well-being, with specific reference to subjective well-being. In addition, health states, in particular the quality of life of older people, as well as a number of other dimensions, such as physical functioning, pain and mental health, play the significant role in the reports (Dolan P., Peasgood T., White M., 2006, p.19-29).

Given the research objectives, we will not suggest an integrated well-being indicator according to this method. Quite the opposite, we would like to pay more attention to the sociological study of the influence of individual social and economic factors on the satisfaction of population needs. Nevertheless, the purpose of the study is obvious: to explore the current state and the possible reaction of the population to changes in living standards and interactions, including those initiated by the government. In this context, the cooperation of the government and scientific organizations in the assessment of customer satisfaction allows us to state that one of the most significant features of social management in developed countries is the prediction and prevention of dissatisfaction by low-quality living and working environment. The prevention of dissatisfaction is just as important as encouragement of motivator satisfaction. Income, therefore, appears to matter for well-being practically in every specialized reports on well-being assessments, including in the above-mentioned paper, but in ways which are far more complex that simply looking at the annual income of the household (Dolan P., Peasgood T., White M., 2006, p.43).

Diener, a famous American scientist, state that "quality of life usually refers to the degree to which a person's life is desirable versus undesirable, often with an emphasis on external components, such as environmental factors and income. In contrast to subjective well-being, which is based on subjective experience, quality of life is often expressed as more 'objective' and describes the circumstances of a person's life rather than his or her reaction to those circumstances." On the contrary, Canadian researchers assume that "overall wellbeing" is roughly synonymous with "quality of life" as in the context of research on wellbeing or quality of life, "measuring what matters" (logo for the Canadian Index of Wellbeing) implies measuring people's lives from the perspectives that are most important to them (The Canadian Index of Wellbeing, 2011, p.5).

Such differences and their own interpretation of the well-being form the basis of the methodology of Canadian researchers. They used a fairly pragmatic approach both to the selection of domain names and specific designations and created a Mandala of Wellbeing where well-being is at the core of the mandala, surrounded by three concentric circles that symbolize the resources we draw upon for our wellbeing, in particular personal, public, and ecosystem resources. The resources that people draw upon for the wellbeing have their own constituents and determinants, i.e.:

personal resources for well-being in the first concentric circle form the core - healthy populations, education, and time use - are the resources that each of us needs to manage our personal well-being;

public resources for well-being in the second concentric circle - living standards, community vitality, leisure and culture, and democratic engagement - are the resources we draw upon from the public domain in which we live, from our local communities to the broader society - living standards, community vitality, leisure and culture, and democratic engagement;

ecosystem resources for wellbeing in the outer circle - environment - encompass and affect all of the other circles and domains (The Canadian Index of Wellbeing, 2011, p.7 - 8).

This comprehensive measuring instrument considering both internal and external environment influencing the formation of motives to participate in the public life of their country and their own development is one of the few examples of integrated assessment of socio-economic factors' impact so far. On the basis of its dynamics it is obvious that there is no direct connection between increasing wealth and other comfort components related to the interaction quality in the society and environmental well-being. In Canada, the 
growth of GDP per capita index is not always accompanied by the growth of the eight-domain CIW over the 1994 to 2008 period. In particular, that the picture presented by GDP per capita is rosier than that presented by the CIW (i.e., $31.0 \%$ compared to $11.0 \%$ ).

Due to the fact that there is no opportunity to compare these factors in Ukraine, the example of Canada allows us to state that ensuring the balance in the society, as well as its economic development also requires a corresponding effort to create a comfortable environment in the society (The Canadian Index of Wellbeing, 2011, p. ix).

Studies on the effects of discomfort in the form of long-term external migration of the population haven't had a large development in Ukraine and in the works of foreign researchers yet. The empirical study in this area is particularly insufficient. In particular, there is only one special model, which allows to determine and to predict the effect of discomfort on the migration of the population: the Harris-Todaro model, named after John R. Harris and Michael Todaro. In the model, equilibrium is reached when the expected wage in urban areas (actual wage adjusted for the unemployment rate), is equal to the marginal product of an agricultural worker. However, the model assumes excessively narrow aspect of comfort: wage (earnings) and unemployment (Harris and Todaro, 1970). Furthermore, due to these factors, the researchers use this model in development economics and welfare economics to explain some of the issues concerning rural-urban migration. The model has considerable scientific acceptance, it is significantly developed by the followers, e.g. in the study of development economics models (Chen, 2014). Its important applications lie in the explanation of the impact of the material component of welfare on the changes in local labour markets. However, this model is not suitable for explaining the influence of a larger number of factors (including social ones) on individual decisions to emigrate. And this last issue is a more difficult choice by the nature of the effects, both for an individual and for society.

In order to select a combination of comfortable living and working environment factors which may affect the external migration of the population, we have analysed the work of the leading researchers in this area, primarily from the Centre on Migration, Policy, and Society (COMPAS), an ESRC-funded Research Centre within the University of Oxford. COMPAS research covers a spectrum of global migration processes and phenomena, from conditions in places of migrant origins, through to institutions and activities affecting mobility, to social and economic effects in receiving contexts. Even though the works of British and other researchers do not offer an empirical model that can be used to justify regulatory decisions, but they have a detailed analysis of the influence of individual social factors on migration. In particular, the researchers pay a lot of attention to the problem of the migration of highly-skilled workers and the consequences associated with it which include even positive one, in particular skills' growth, "social transfers" and others. The possibility of high earnings plays the primary role among the factors influencing decision-making process (Vargas-Silva, C., 2011). The scientists from the countries where immigration became a significant issue have mainly focused on the material constituents of comfort as the pull factors: the quality of social welfare in the recipient country, especially social security in periods of job search etc. (Czaika, M., H. Haas, 2011; Spencer, S.. et al, 2010; Thieleman, E., 2004). In this direction the factors migratory activity excreted in the order of selection tools restrictive immigration or at least, ensure regulatory effect on its volume.

Inspecting the aspect of the causes of external migration, analysis of a larger number of factors 'pushing' or 'pulling' the migrants can be found in other works. For instance, a study analysing migration trends in the United States (Castles, S., 2004) the author stresses the importance of political stability, respect for rights, development of civil society institutions in shaping migration trends. These and some other factors of discomfort and life dissatisfaction grounded as a factors of emigration in researches considering the problem of migration in Central and Eastern Europe (Otrachshenko, V., Popova, O., 2013) and deprived post-Soviet countries (Lapshyna I., Düvell F., 2015). 
We believe that there is a study that is one of the most intricate works in which migration is associated with the comfort factors (Chappell, L. et al, 2010). The report for the study includes analysis of the reasons that individual migrants gave for their migration, and although this is not the same as a 'determinant' of migration, it is again broadly consistent with other evidence in showing that employment opportunities and higher wages as a way to increase household income are major factors in the migration decision, alongside a desire to pursue education or to join family members abroad. Thus, the main emphasis in the study was made on the analysis of the reasons that individual migrants gave for their migration, and not on social life and relations in society. However, this and other investigations, in particular (Castles, S., 2004), may become the theoretical basis for selecting comfort factors in living and working environment to build the economicmathematical model of external migration.

\section{PECULIARITIES OF COMFORT ASSESSMENT IN UKRAINE}

In Ukraine, the assessment of regional human development most heavily investigates the problems of providing comfortable living and working conditions, the assessment is based on the methodology developed by the specialists of the Institute for Demography and Social Studies of the National Academy of Sciences of Ukraine of Ukraine in 2012. This integral index of human development in the regions of Ukraine is the only integrated method in Ukraine which can be considered the most tangential to the assessment of socio-economic comfort of the population. Even though, the objectives for creating it were absolutely different. The index accounts for a certain group of indicators characterizing the level of satisfaction of the basic personal and social needs as all foreign systems do. The needs in Ukrainian method include human reproduction, social status, decent work, welfare, education and a comfortable life (IDSS). The difference of the national methodology lies in the use of statistical data in the calculation of fractal and general indicators, which allows obtaining reliable results. However, the absence of subjective estimates of the population, as well as the inclusion of performance indicators characterizing mainly the degree of physical and economic availability of individual public goods reduces the possibility to analyse the relevance of such needs and their impact on the human behaviour, including the formation of the motives for economic activity and involvement in public life that relates to the comfort research goals.

Given the advances in monitoring conditions for need satisfaction in the society, and relying on the methodological and methodical fundamentals of the analysis suggested by the foreign scientists, we believe that the essence of the disagreement on the meaning of terms such as comfort and well-being is solely glossarial due to differences in the terminology development in the First World (so-called capitalist and democratic countries) and the post-Soviet states, also collectively known as the former Soviet Union (FSU).

Social comfort, as well as well-being, can be interpreted as a subjective feeling of satisfaction at having your needs - both material and socio-psychological (spiritual, emotional) - satisfied that creates positive motives to interact in society and the full implementation of the human capacity, including work opportunities.

If the basic needs are not satisfied, dangerous individual decisions may be made both in meso- and macroeconomic sense due to the noted discomfort. In particular, the decision to emigrate may be the extreme expression of discomfort in the home country. The methodological principles adopted by the UNDP experts to monitor emigration notes: "Migrants' transfers are defined as the net worth of migrants who are expected to remain in the host country for more than one year that is transferred from one country to another at the time of migration" (UNDP, 2013, p.185). So emigration and its further consequences can cause deteriorating demographic and economic situation trends, both current and future ones: social orphanhood 
of migrants' children, irreversible loss of working age people, including loss of those most likely to have education and skills etc.

These trends are very risky for Ukraine where there are high migration losses of working age people, but studies of the comfort impact upon the decision to migrate are very occasional and relate to the disjointed aspects, mainly the loss of intellectual capital. We suggested using the statistical method for comfort evaluation in one of our papers (Grisznowa O., Miszczuk H., 2013). At the same time, we are aware that apart from the assessment results, providing opportunities designed to affect migration are also extremely important. It is therefore vital to analyze the relationship between emigration and the widest possible range of socio-economic comfort components, as well as their use as factors to replicate the impact on the migratory behaviour of the population.

\section{DATA ANALYSIS}

\section{Empirical Model}

In order to test the hypothesis that emigration factors may be associated with need satisfaction, i.e. with the level of comfort of socio-economic living and working environment, we have carried out statistical study basing on the socio-economic approach.

While verifying the hypothesis about the existence of economic-mathematical link between emigration and a number of social and economic factors that characterize comfortable living environment, it is necessary to choose the appropriate type of empirical model and adapt it to the purposes of our research. At this moment there are no special models that study the influence of comfort factors of the living and working environment (especially given the intangible constituents of comfort) upon the decision to emigrate. The existing models, in particular, the Harris-Todaro model, has a different purpose and level of application, as it was proven in the literature review. Therefore, we suggest using one of the universal economic-mathematical models which allows estimating the influence of many factors upon discomfort in the form of long-term external migration - linear regression model based on free (additive) convolution (1):

$$
y=a_{0}+\sum_{i=1}^{n} a_{i} x_{i}+\varepsilon,
$$

where $y$ is a dependent variable, emigrant population as a percentage of total population, \%; a variable $x_{i}$ states for each factor characterizing comfort of living and working in the home country; $i$ is the factor's number; $n$ is the factors' quantity; $a_{0}, a_{i}$ are the parameters of the model; and $\varepsilon$ presents the remains of the model.

We analysed the possible relationship of social and economic factors and their impact on external emigration for a group of 20 European countries. We included the countries with high and highest socioeconomic development and close neighbours of Ukraine from among the FSU which today, thanks to advances in socio-economic reforms, are EU member states in a pool analysis.

The choice of factors was carried out on the basis of the existing criteria theoretical assessment of the impact of the environment on migration activity (Castles, S., 2004), (Chappell, L., et al, 2010). We agree with the authors on the importance of such factors as fairness in society, respect for civil rights and material constituents of well-being. However we went further and specified the list of factors taking into account the availability of statistical information in order to use them for the external migration analysis and to build an economic-mathematical model.

In particular, we used the income index, job satisfaction, and the standard of living in the group of material comfort factors. We also chose factors that are associated with material constituents, but they mostly 
describe the availability level of basic needs and satisfaction with the state of social infrastructure and social development of the selected country. Those include Travel \& Tourism Competitiveness Index (TTCI), Life Expectancy Index, satisfaction with health care quality, adolescent fertility rate, and the index of overall life satisfaction.

We expanded the factors of justice and relations in society by taking into account the Gender Inequality Index (GII), the Democracy Index, the WJP Rule of Law Index, Corruption Perceptions Index (CPI), and Government Effectiveness Index (GEI).

The Global Innovation Index (GII) and Knowledge Index (KI) are the factors of country's potential empowerment.

Apart from that, we analyzed appropriate integrated indicators - the Happy Planet Index (HPI), wellbeing, and the Number of Happy-Life-Years (HLY) - not to build the model, but to characterize the influence of well-being factors upon external migration.

Hence the given factors were selected in accordance with the theoretical framework defined in the works (Castles, S., 2004), (Chappell, L., et al, 2010), partly (Thieleman, E., 2004), we used them as an array of independent variables that may affect the external migration of the population. They allow assessing the totality of existing capacities to satisfy both material and socio-psychological needs of the population.

\section{Analysis}

The results of our correlation analysis confirm the existence of a logical connection between the comfort factors of the living and working environment of the population and emigration (table 1).

The factors are presented in descending order according to the relation closeness. As the table shows, the factors which are purely material in their nature (the standard of living and the income index) and those which cannot be uniquely associated only with the satisfaction of material needs (job satisfaction, well-being as one of the partial HPI indexes, and the index of overall life satisfaction) have the most significant influence on emigration. However, the significant influence of the factors which characterize the overall social comfort of living in the country - GII, adolescent fertility rate, satisfaction with education and health care quality, life expectancy as an integral characteristic of the citizens' standard of living, as well as the democracy development, rule of law, corruption, government efficiency - is also obvious. Even though the correlation with government efficiency is insufficiently significant from a mathematical point of view, its impact was still quite high -0.597 . The factors of the overall economic success of the home country appeared to play an important role in the formation of the motives of emigration, too. Those aspects can be considered as the general characteristics of the progress of an employment and other human development opportunities: high-skilled activities development and their distribution in the economy (KI and GII).

The other factors which are not shown in the table also confirm the influence of the well-being factors upon the use of the labour force in Ukraine. As a result of using the appropriate source data from special studies we identified, in particular, the high impact of the HPI calculated according to the United Nations method $(-0.682)$ - output data are available on the website (World Happiness Report, UN, 2013) - and the standard of living (-0.716). It's worth saying that the standard of living was studied only once, in 2005 (The Quality of Life Index, 2005), which makes it impossible to use it as a permanent element of the monitoring. In addition to that, the influence of the factors introduced by the Legatum Institute in its Prosperity Index as components relating to subjective well-being - personal freedom (0.509) and social capital (0.5477) - is also very high, though not quite significant in the mathematical sense. The relevant data for the connection assessment are available from the special report (The Legatum Prosperity Index, 2014). 


\begin{tabular}{|c|c|c|c|c|c|c|c|c|c|c|c|c|c|c|c|c|c|c|c|c|c|c|}
\hline 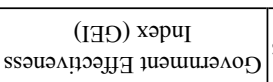 & $2=$ & $\begin{array}{lll}\exists & \infty \\
0 & & \infty\end{array}$ & \begin{tabular}{l|l}
$\infty$ \\
0 \\
0
\end{tabular} & 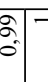 & $=$ & \begin{tabular}{l|l}
$n$ & \\
$\infty$ & \\
0 & \\
0 &
\end{tabular} & $\hat{0}$ & $\bar{\sigma}$ & $\begin{array}{l}\overline{0} \\
0\end{array}$ & $\hat{0}^{\circ}$ & $\begin{array}{l}3 \\
0 \\
0\end{array}$ & 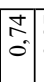 & $\begin{array}{l}\hat{\sigma} \\
\hat{o}\end{array}$ & \begin{tabular}{|l|}
$\overrightarrow{0}$ \\
0
\end{tabular} & $\begin{array}{l}9 \\
\text { ले } \\
\text { के }\end{array}$ & 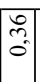 & \begin{tabular}{l|}
$\infty$ \\
0 \\
0
\end{tabular} & \begin{tabular}{l|} 
\\
$\stackrel{2}{0}$ \\
0
\end{tabular} & $\begin{array}{l}0 \\
0 \\
0\end{array}$ & 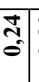 & $\begin{array}{l}\text { के } \\
\text { o. }\end{array}$ & $\begin{array}{l}\hat{n} \\
\hat{n} \\
0 \\
1\end{array}$ \\
\hline 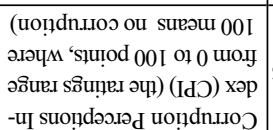 & $\infty$ & $\bar{m} \mid \overline{7}$ & 78 & ৪াঃ & 87 & $\nabla$ & $g$ & 2 & 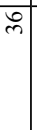 & in & \% & $\mid \vec{q}$ & \begin{tabular}{|l|l|} 
\\
$\infty$
\end{tabular} & $\infty$ & 夺 & $\infty$ & 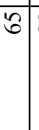 & $\infty$ & $\vec{q}$ & ¿ू. & $\frac{7}{4}$ & $\begin{array}{l}\text { mo } \\
0 \\
0 \\
1\end{array}$ \\
\hline 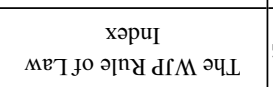 & $=\frac{9}{0}$ & \begin{tabular}{l|l}
$m$ & 5 \\
\hdashline & 4 \\
0
\end{tabular} & : & 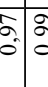 & 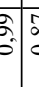 & \begin{tabular}{l|l} 
& \\
$\infty$ \\
0 \\
0
\end{tabular} & $\begin{array}{l}\infty \\
n \\
n \\
0\end{array}$ & $\begin{array}{l}2 \\
\infty \\
0\end{array}$ & 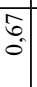 & \begin{tabular}{l}
0 \\
\hdashline \\
0
\end{tabular} & $\begin{array}{l}0 \\
0 \\
0\end{array}$ & $\mid$\begin{tabular}{l}
$n$ \\
\hdashline \\
0
\end{tabular} & -1 & $\frac{\nabla}{\Delta}$ & $\begin{array}{l}\text { nे } \\
\text { ô }\end{array}$ & $\frac{9}{0}$ & \begin{tabular}{l|} 
\\
$\infty$ \\
0 \\
0
\end{tabular} & बे & 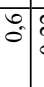 & $\begin{array}{l}\text { N1 } \\
\text { - }\end{array}$ & $\overline{\bar{o}}$ & $\begin{array}{l}n \\
0 \\
0 \\
1\end{array}$ \\
\hline хәри Кэ..эошәД әЧІ & $\stackrel{d}{d}$ & 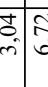 & \begin{tabular}{l|l}
$\frac{1}{N}$ & \multirow{2}{*}{} \\
0 &
\end{tabular} & 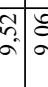 & \begin{tabular}{l|l}
0 \\
0 \\
0
\end{tabular} & $\begin{array}{ll}\infty \\
\infty \\
\infty \\
\sim\end{array}$ & $\begin{array}{l}n \\
n \\
n\end{array}$ & $\begin{array}{l} \\
\text { गे } \\
\infty\end{array}$ & \begin{tabular}{l}
0 \\
\hdashline \\
-
\end{tabular} & \begin{tabular}{l|}
\multirow{2}{*}{} \\
6े.
\end{tabular} & $\begin{array}{l}\Delta \\
\end{array}$ & \begin{tabular}{|l}
\multirow{2}{*}{} \\
$\stackrel{2}{n}$ \\
\end{tabular} & $\begin{array}{l} \\
\hat{\alpha}\end{array}$ & $\underset{7}{\pi}$ & 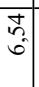 & \begin{tabular}{|l|} 
\\
mi
\end{tabular} & \begin{tabular}{l|} 
\\
0 \\
$\infty$ \\
$\infty$
\end{tabular} & $\begin{array}{l}m \\
\hat{a}\end{array}$ & $\begin{array}{l}0 \\
\qquad \\
n\end{array}$ & $\begin{array}{l}\vec{a} \\
\text { nो }\end{array}$ & $\begin{array}{c}\bar{\sim} \\
\infty \\
\infty\end{array}$ & 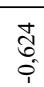 \\
\hline 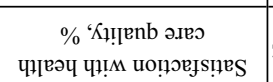 & $=$ & \begin{tabular}{l|l}
$\infty$ \\
$m$ & $m$
\end{tabular} & iो & $\vec{\infty} \mid \ddot{b}$ & $\begin{array}{lll}0 \\
0\end{array}$ & $\infty$ & $\infty$ & $\bowtie$ & ते & t & $n$ & \begin{tabular}{|l|}
$\infty$ \\
\end{tabular} & 命 & F & $\approx$ & $\hat{\imath}$ & 寺 & $\vec{\infty}$ & 8 & $\infty$ & 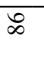 & ?o \\
\hline 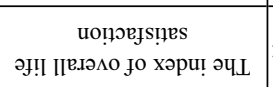 & \pm in & \begin{tabular}{l|l}
$n_{n}$ & 7
\end{tabular} & \begin{tabular}{l|l}
$r$ & $n$ \\
+ & $n$
\end{tabular} & \begin{tabular}{l|l}
$n$ \\
$n$
\end{tabular} & $\bar{F}$ & $\begin{array}{l}0 \\
0 \\
6\end{array}$ & $\begin{array}{l}m \\
+\end{array}$ & $\widehat{6}$ & $\vec{n}$ & F & $\begin{array}{l}\infty \\
i n\end{array}$ & $\vec{n}$ & $\therefore$ & in & $\begin{array}{l} \\
\text { in }\end{array}$ & \begin{tabular}{|l|} 
\\
in
\end{tabular} & ?ु. & $\begin{array}{l}0 \\
\therefore\end{array}$ & $\begin{array}{l}m \\
\text { in }\end{array}$ & $n$ & $\hat{\sigma}$ & \begin{tabular}{l}
$\infty$ \\
\multirow{6}{0}{} \\
0 \\
1
\end{tabular} \\
\hline хәри Кэиеџюәdх马 әЈ!Т & $=\frac{n}{2}$ & 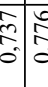 & $\begin{array}{lll}0 & \infty \\
0 & \infty & \infty \\
0 & \infty\end{array}$ & \begin{tabular}{l|l}
$\hat{\infty}$ & 2 \\
$\infty$ & 0 \\
$\infty$ & 0 \\
0 & 0
\end{tabular} & فे & ڤ.) & $\begin{array}{l}\mathrm{O} \\
\hat{0}\end{array}$ & $\begin{array}{l}\widehat{\widehat{\sigma}} \\
\hat{\sigma}\end{array}$ & $\begin{array}{l}\hat{a} \\
\dot{\infty} \\
\hat{0}\end{array}$ & $\begin{array}{l}\infty \\
\infty \\
0\end{array}$ & $\begin{array}{c}\hat{n} \\
\hat{\sigma}\end{array}$ & \begin{tabular}{|l|} 
\\
$\infty$ \\
5 \\
0
\end{tabular} & 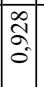 & $\mid \begin{array}{l}1 \\
\infty \\
\infty \\
0 \\
0\end{array}$ & ह & $\begin{array}{l}2 \\
\dot{0} \\
0 \\
0\end{array}$ & $\hat{\sigma}$ & $\begin{array}{l}\hat{n} \\
\hat{\sigma}\end{array}$ & $\frac{?}{\tilde{O}}$ & $\begin{array}{l}-1 \\
\infty \\
0 \\
0\end{array}$ & 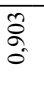 & 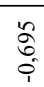 \\
\hline 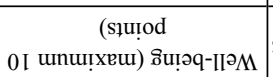 & $\simeq$ in & \begin{tabular}{l|l}
$n$ & 7 \\
$n$ & 7
\end{tabular} & \begin{tabular}{l|l}
$r$ & $\infty$ \\
+ & 1
\end{tabular} & \begin{tabular}{l|l}
$\infty$ & $\checkmark$ \\
$\sim$ &
\end{tabular} & $\nabla g$ & \begin{tabular}{l|l}
$\infty$ \\
0 \\
0
\end{tabular} & $\vec{f}$ & $\widehat{6}$ & $\begin{array}{l}\infty \\
\infty \\
\text { n. }\end{array}$ & F & $\vec{\sigma}_{0}$ & F & \begin{tabular}{|l|} 
\\
$\therefore$ \\
$\therefore$
\end{tabular} & $\begin{array}{l}\infty \\
\text { in }\end{array}$ & ने & \begin{tabular}{|l|}
$n$ \\
$n$ \\
$n$
\end{tabular} & तु & $n$ & $\begin{array}{l}n \\
n\end{array}$ & जी & r & $\underset{0}{\stackrel{\infty}{*}}$ \\
\hline 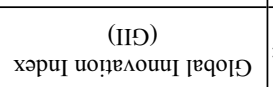 & $=\overline{\hat{c}}$ & 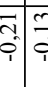 & $\begin{array}{lll}2 & 0 \\
0 & 0 & 0\end{array}$ & $=-\infty$ & -1 & 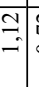 & $\begin{array}{l}1 \\
0 \\
0 \\
0 \\
0\end{array}$ & $\begin{array}{l}\mathrm{I} \\
=\end{array}$ & $\begin{array}{l}\mathrm{N} \\
\mathrm{0}\end{array}$ & $\begin{array}{l}\vec{n} \\
0 \\
\end{array}$ & \begin{tabular}{|l|}
$\overrightarrow{0}$ \\
-
\end{tabular} & $\begin{array}{l}\mathrm{N} \\
0\end{array}$ & \pm & $\begin{array}{c}1 \\
0 \\
0 \\
1\end{array}$ & $\begin{array}{l}\text { సे } \\
0 \\
1\end{array}$ & \begin{tabular}{|l|} 
\\
0 \\
0 \\
1
\end{tabular} & $\hat{\sigma}$ & $\begin{array}{l}\vec{f} \\
- \\
-\end{array}$ & 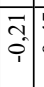 & 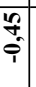 & $\stackrel{\mathcal{T}}{\sim}$ & $\underset{\stackrel{N}{N}}{\hat{i}}$ \\
\hline (ГУ) хәри әઠิрә[мочу & $\circ \sqrt{6}$ & \begin{tabular}{l|l}
1 & \\
6 & 0 \\
0 & 0
\end{tabular} & (]) & बढ & \begin{tabular}{c|c} 
\\
aे \\
âd
\end{tabular} & $\left.\begin{array}{l|l}0 \\
0 \\
\infty \\
\infty\end{array}\right]$ & $\begin{array}{l}\stackrel{g}{q} \\
f\end{array}$ & \begin{tabular}{|l|}
$\infty$ \\
$\infty$ \\
$\infty$
\end{tabular} & $\begin{array}{ll}4 \\
\\
\end{array}$ & $\frac{2}{n}$ & 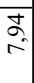 & $\begin{array}{ll} \\
\sim \\
n\end{array}$ & \begin{tabular}{l|}
2 \\
$\infty$ \\
$\infty$
\end{tabular} & $\frac{1}{2}$ & ?̧ & \begin{tabular}{|l|}
\multirow{2}{*}{} \\
के
\end{tabular} & \begin{tabular}{l} 
\\
\multirow{2}{*}{} \\
$\infty$
\end{tabular} & $\begin{array}{l}\infty \\
2 \\
2 \\
2\end{array}$ & $\begin{array}{ll}\infty \\
+\infty \\
+\end{array}$ & हु. & $\begin{array}{l}\overline{6} \\
\infty\end{array}$ & $\underset{\hat{N}}{\hat{i}}$ \\
\hline 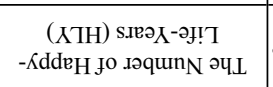 & to & \begin{tabular}{l|l} 
\\
+
\end{tabular} & 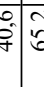 & 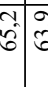 & है। & $\frac{m}{6} \mid$ & $\overrightarrow{\hat{q}}$ & 8 & $\begin{array}{l}\sim \\
\stackrel{n}{n} \\
\stackrel{n}{n}\end{array}$ & $\vec{f}$ & $\begin{array}{l}\infty \\
\infty \\
\infty \\
n\end{array}$ & $\vec{f}$ & $\begin{array}{l}m \\
\cos _{0}^{\circ}\end{array}$ & $\frac{3}{n}$ & $\begin{array}{l}\text { fे } \\
\dot{f}\end{array}$ & 竎 & $\begin{array}{l}+ \\
i n \\
n\end{array}$ & $\begin{array}{l}0 \\
0 \\
0\end{array}$ & $\begin{array}{c}\sim \\
\infty \\
\infty\end{array}$ & $\begin{array}{c}\text { ga } \\
\text { mats }\end{array}$ & $\stackrel{\infty}{6}$ & $\bar{m}$ \\
\hline 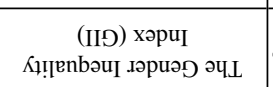 & $\infty$ & 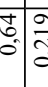 & 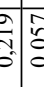 & 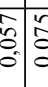 & $\begin{array}{l}n \\
0 \\
0 \\
0\end{array}$ & \begin{tabular}{l|l}
0 & \\
0 & 1 \\
0 & 1 \\
0 &
\end{tabular} & 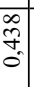 & \begin{tabular}{|l|}
$n$ \\
0 \\
0 \\
0
\end{tabular} & \begin{tabular}{|l|}
0 \\
\hdashline \\
\\
\end{tabular} & 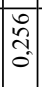 & $\begin{array}{l}1 \\
\\
0 \\
0 \\
0\end{array}$ & \begin{tabular}{|l|} 
\\
$\tilde{N}$ \\
0
\end{tabular} & $\begin{array}{l}\mid n \\
0 \\
0 \\
0 \\
0\end{array}$ & $\frac{0}{0}$ & 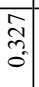 & 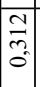 & $\begin{array}{l}0 \\
\hat{0} \\
0\end{array}$ & $\begin{array}{l}n \\
2 \\
0 \\
0\end{array}$ & $\begin{array}{l} \\
0 \\
0 \\
3 \\
0\end{array}$ & 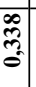 & 垈 & $\underset{0}{\frac{F}{t}}$ \\
\hline 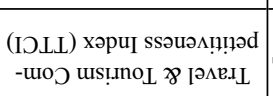 & & 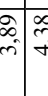 & 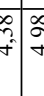 & \begin{tabular}{l|l}
$\infty$ & \\
$\vdots$ & \\
+ &
\end{tabular} & $\vec{n}$ & $\begin{array}{l}\vec{n} \\
n\end{array}$ & $\bar{f}$ & $\begin{array}{c}\text { ले } \\
\text { ஸे }\end{array}$ & 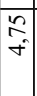 & $\begin{array}{l}\vec{n} \\
+ \\
+\end{array}$ & $\begin{array}{l}\partial \\
f\end{array}$ & \begin{tabular}{|l}
$\stackrel{f}{f}$ \\
$f$
\end{tabular} & $\begin{array}{l}2 \\
\approx \\
\dot{\sigma}\end{array}$ & $\underset{f}{\tilde{f}}$ & $\begin{array}{l}\text { I } \\
\dot{f}\end{array}$ & $\begin{array}{l}0 \\
0 \\
f\end{array}$ & $\begin{array}{l}\infty \\
\infty \\
n \\
n\end{array}$ & $\begin{array}{l}\text { ì } \\
\text { in }\end{array}$ & \begin{tabular}{l} 
J \\
\multirow{8}{*}{}
\end{tabular} & $\begin{array}{l}\infty \\
\text { ले } \\
\text { ले }\end{array}$ & $\begin{array}{l}\infty \\
m \\
i n\end{array}$ & $\frac{\vec{n}}{\tilde{c}}$ \\
\hline 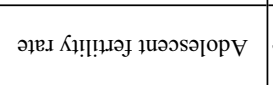 &. & 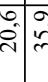 & हे & 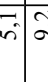 & 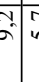 & ती & $\begin{array}{l}\infty \\
\infty \\
0 \\
0\end{array}$ & \begin{tabular}{|l|}
$\infty$ \\
$\infty$
\end{tabular} & $\Rightarrow$ & $\overrightarrow{\mathrm{c}}$ & $\theta$ & $\begin{array}{l}n \\
m \\
m\end{array}$ & \begin{tabular}{|l|}
$\infty$ \\
$\sim$
\end{tabular} & ב & $\bar{m}$ & \begin{tabular}{|l|} 
\\
$\mathrm{a}$
\end{tabular} & $\begin{array}{l}0 \\
0 \\
0\end{array}$ & ?n & 商 & ली & $\begin{array}{l}\infty \\
n \\
n\end{array}$ & $\begin{array}{l}\hat{0} \\
\hat{0}\end{array}$ \\
\hline хәри! әшоэи! әЧL & 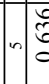 & 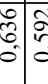 & 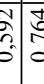 & 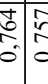 & $\frac{0}{5}$ & \begin{tabular}{l|l}
2 & 0 \\
2 & 0 \\
0 &
\end{tabular} & 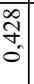 & \begin{tabular}{|l|}
$\vec{y}$ \\
0 \\
\end{tabular} & $\begin{array}{l} \\
\forall \\
0 \\
0\end{array}$ & $\left|\begin{array}{l}\infty \\
0 \\
0 \\
0 \\
0\end{array}\right|$ & $\begin{array}{l}0 \\
6 \\
0 \\
0\end{array}$ & $\mid \begin{array}{c}\infty \\
\infty \\
n \\
0\end{array}$ & $\begin{array}{l}\hat{2} \\
\hat{2} \\
0\end{array}$ & $\begin{array}{l}1 \\
\text { Ŝ. } \\
0 \\
0\end{array}$ & 苾 & 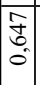 & $\begin{array}{l}0 \\
2 \\
0 \\
0\end{array}$ & 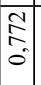 & 药 & 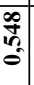 & $\stackrel{2}{2}$ & $\begin{array}{l}\infty \\
\infty \\
0 \\
i\end{array}$ \\
\hline 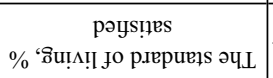 & & m. & रे| & \begin{tabular}{l|l}
$\infty$ & $\infty$ \\
$\infty$ & $\infty$
\end{tabular} & \begin{tabular}{l|l}
$\infty$ & 2 \\
$\infty$ & 2
\end{tabular} & $\infty$ & $\stackrel{\Delta}{\Delta}$ & 요 & \begin{tabular}{|l|}
$\infty$ \\
$m$
\end{tabular} & 암 & 6 & ñ & 2 & 8 & 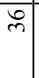 & 午 & $\stackrel{\infty}{\infty}$ & ㅇ & $n$ & ম & $\infty$ & $\begin{array}{l}0 \\
\stackrel{2}{6} \\
1\end{array}$ \\
\hline $\begin{array}{c}\text { poys!̣es } \\
\text { \% 'uọ̣ozjs!̣es qor }\end{array}$ & & d & ע/ & ลू & 52 & $\bar{\infty}$ & in & $\bar{a}$ & $\cong$ & $\cong$ & $\infty$ & $\approx$ & a & $\infty$ & 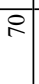 & 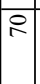 & $\infty$ & 8 & $\pi$ & 5 & $\infty$ & $\begin{array}{l} \pm \\
\infty \\
\infty \\
0 \\
1\end{array}$ \\
\hline
\end{tabular}

$\%$ 'uo!̣e [ndod

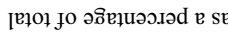

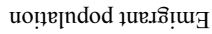

K.nunoว

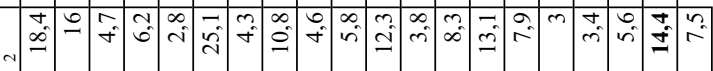


These results confirm the high importance of the comfortable living and working environment in the home country to ensure the labour potential reproduction, its development and use for the benefit of the country.

Hence to understand the results of measuring the relationship of social and economic factors more deeply and to use it in order to manage the constituents of the comfortable development environment and labour potential use, we developed the corresponding mathematical model.

We used Microsoft Excel's built-in regression function to build and analyze the adequacy of the model. This allowed us not only to quickly discover a mathematical relationship between the factors, but also to assess the suitability of the results obtained on the basis of Fisher's optimization criterion, Student's criterion, correlation coefficient, and coefficient of determination.

Finally, in the step-by-step evaluation of the impact of the above factors (table 1) on the emigration of the population based on the multivariate regression model we determined that the five-factor model (2) would be statistically significant and adequate. Thus, for sake of efficiency and classification we divided the range of possible values that $x_{i}$ can take, into five components of the model which simultaneously meet economic logics and the opportunities to improve public management of social sphere. The five-factor model was setup as follows:

$$
y=-3,50-0,35 x_{1}-46,42 x_{2}+69,32 x_{3}-38,34 x_{4}+0,55 x_{5}
$$

Where $y$ is a dependent variable, emigrant population as a percentage of total population, \%; a variable $x_{1}$ states for percentage of the population satisfied with the standard of living; $x_{2}$ is the income index; $x_{3}$ is the Life Expectancy Index; $x_{4}$ is the WJP Rule of Law Index; and $x_{5}$ presents the CPI.

The table 2 shows the results of the model validation based key statistical indicators.

\section{Table 2}

The results verifying the validity of the economic-mathematical model of external migration based on key statistical indicators

\begin{tabular}{|c|c|c|}
\hline$\#$ & Indicators & Calculated Value \\
\hline 1 & Multiple Correlation Coefficient & 0,923 \\
\hline 2 & Coefficient of Determination & 0,853 \\
\hline 3 & F-statistics (critical value for this model is $\mathrm{F}=\mathbf{2 , 9 6}$ ) & 16,22 \\
\hline 4 & t-statistics (critical value for the model $\mathrm{t}=\mathbf{2 , 1 4})$ & \\
\hline 4.1 & $x_{1}$ & 4,38 \\
\hline 4.2 & $x_{2}$ & 3,24 \\
\hline 4.3 & $x_{3}$ & 3,07 \\
\hline 4.4 & $x_{4}$ & 3,84 \\
\hline 4.5 & $x_{5}$ & 4,23 \\
\hline
\end{tabular}

Source: compiled by the authors.

The calculation presented in the table 2 suggests that the constructed model has a high theoretical efficiency and is suitable for practical use. 


\section{CONCLUSIONS AND RECOMMENDATIONS}

This paper has obtained a wide range of values of the statistical parameters of the model which allow us to conclude that health care needs and conditions for the prolongation of life have the primary relevance in modern conditions (the relevance of Life Expectancy Index is the highest). However, the need to ensure the material component of a comfortable life and observance of human rights, as well as their protection remain very important (this is defined by the significance parameters for the income index and the Rule of Law Index).

Given the low quality of medical services in Ukraine which together with other factors (industrial injuries, excess morbidity and mortality, lack of preventive care and culture of maintaining a high level of health) leads to low life expectancy, the guidelines for measurement perhaps need to be more precisely specified in this case. A part of issues in health care is recognized on the national level and is one of the priority directions of social sphere reforms presented by the new government. Other problems, primarily response to manufacturing injury prevention, still have to be resolved through the dialogue with the owners of the enterprises, working conditions' improvement etc. Apart from that, creating a new way of life of Ukrainians is essential: the development of cultural influences on consciousness at the national level should play a central role.

If we consider the aspect of ensuring a decent income, which would encourage people to work in their home country, as well as unconditional respect for human rights on the basis of strengthening the rule of law, these push and pull migration factors are also within the scope of government competence - through the acceleration of the implementation of anti-corruption reforms, simplification of business conditions, and, most importantly, reducing population stratification by income on the principles of social responsibility and justice. These long-awaited reforms of the Ukrainian society relate to the requirements of the European community. The delay in their execution has become a major barrier for the European integration of Ukraine. The results of the analysis once more provide evidence that implementing these tasks is vital not only for political reasons: the decision to emigrate is one of the most difficult choices, but after making it, $14.4 \%$ of the Ukrainian population (table 1) emphasized the urgent need for comfort in their country.

In terms of good practice for ensuring the comfort of living and working in Ukraine, unfortunately, one cannot implement any priority actions in this field even with the construction of similar economicmathematical model in terms of regions or other dynamic model. Until relevant comparable data that would adequately characterize these aspects of comfort has been collected, however, this task will be very hard to fulfil. Consequently, understanding and improving well-being in Ukraine requires a sound evidence base that can inform policy-makers and citizens alike where, when, and for whom life is getting better. Therefore, the specification of management actions in this direction requires the development of social dialogue in the society and specification of the main ways of solving the existing problems. This entire agenda should include the process of constant interaction, coordination of funding areas which are most relevant to the community's projects, the formation of stable relations enabling bottom-up participation in addressing critical issues of labour potential development.

\section{REFERENCES}

Castles, S. (2004), The Factors That Make and Unmake Migration Policies, International Migration Review, Conceptual and Methodological Developments in the Study of International Migration, Vol. 38, No. 3, Fall, 2004, pp. 852-884. [Online] Available from: http://www.jstor.org/stable/27645419. 
Chappell, L. et al (2010), Development on the Move: Measuring and Optimising Migration's Economic and Social Impacts', London: ippr [Online] Available from: http://www.un.org/esa/population/meetings/ninthcoord2011/ippr-gdn. pdf.

Chen, X.S. (2014) 'Computational Forms of Economic Development Models' [Online] Available from: http://www.laits. utexas.edu/compeco/Chen.pdf.

Cornell University, INSEAD, and WIPO (2014), The Global Innovation Index 2014: The Human Factor in innovation, Fontainebleau, Ithaca, and Geneva,pp. 290-293. [Online] Available from: http://www.globalinnovationindex.org/ userfiles/file/reportpdf/GII-2014-v5.pdf.

Czaika, M. and H. de Haas (2011), The Effectiveness of Immigration Policies: A Conceptual Review of Empirical Evidence. Working Paper 33, International Migration Institute, University of Oxford, April 2011 [Online] Available from: http://www.imi.ox.ac.uk/pdfs/wp/wp-33-11.

Dolan, P.,Peasgood, T. and White, M. (2006), Review of research on the influences on personal well-being and application to policy making'. Final report to Defra. London: Tanaka Business School, Imperial College London; Centre for Well-being in Public Policy, University of Sheffield, 193 p.

Economist Intelligence Unit (2005), The Quality of Life Index. [Online] Available from: http://www.eiu.com/.

Grisznowa, O., Miszczuk, H. (2013), Social Comfort as Authorities' Social Responsibility Indicator', Zeszyty Naukowe Uczelnia Warszawska im. Marii Sktodowskiej-Curie. Kwartalnik, vol. 2 (40), pp.75 - 87.

Harris, J., and Todaro, M. (1970), Migration, Unemployment, and Development: A Two-Sector Analysis, American Economic Review, pp. 126 - 142. [Online] Available from: https://www.aeaweb.org/aer/top20/60.1.126-142.pdf.

Helliwell, J. F., Layard, R. and Sachs J., eds. (2013), World Happiness Report 2013. New York: UN Sustainable Development Solutions Network. [Online] Available from: http://unsdsn.org/wp-content/uploads/2014/02/WorldHappinessReport2013_online.pdf.

IDSS: Methodology of regional Human Development Assessment. Kyiv: the Institute for Demography and Social Studies named after M.V. Ptukha of the National Academy of Sciences of Ukraine of Ukraine [Online] Available from: http://www.idss.org.ua/\#.

Lapshyna I., Düvell F. (2015), Migration, life satisfaction, return and development: the case of a deprived post-Soviet country (Ukraine), Migration and Development, DOI: 10.1080/21632324.2015.1022084

Michalos, A.C., Smale, B., Labonté, R., Muharjarine, N., Scott, K., Moore, K., Swystun, L., Holden, B., Bernardin, H., Dunning, B., Graham, P., Guhn, M., Gadermann, A.M., Zumbo, B.D., Morgan, A., Brooker, A.-S., \& Hyman, I. (2011), The Canadian Index of Wellbeing. Technical Report 1.0. Waterloo, ON: Canadian Index of Wellbeing and University of Waterloo, 80 凶.

Official Economist Intelligence Unit web-site (2013), The Democracy Index 2012. [Online] Available from: http://www. eiu.com/.

Official Transparency International web-site (2013), Corruption Perceptions Index [Online] Available from: http://www. transparency.org/cpi2013/results.

Otrachshenko, V., Popova, O. (2013), Life (dis)satisfaction and the intention to migrate: Evidence from Central and Eastern Europe, Journal of Socio-Economics 48: 40-49. Retrieved from: http://ssrn.com/abstract=2364407

Spencer, S., et al. (2010), 'Economic gain, political cost', in Finch, T. and Goodhart, D. (eds). London: IPPR \& Prospect, pp.19-21. [Online] Available from: http://www.ippr.org/assets/media/images/media/files/publication/2011/05/Immigration\%20under\%20Labour\%20Nov2010_1812.pdf.

The Legatum Institute Foundation (2014), The Legatum Prosperity Index. [Online] Available from: http://www.prosperity.com/\#!/principles-of-prosperity.

The Longman Dictionary of Contemporary English (1992), in 2 vol., Moscow: Rus. Yaz., Vol. 2, 1229 p.

The New Economic Foundation. (2012), The Happy Planet Index Report: A global index of sustainable well-being. [Online] Available from: http://www.neweconomics.org/publications/entry/happy-planet-index-2012-report. 
Thielemann, E. (2004), 'Does Policy Matter? On Governments' Attempts to Control Unwanted Migration', CCIS Working Paper No. 112, The Center for Comparative Immigration Studies, University of California, San Diego. [Online] Available from: http://personal.lse.ac.uk/thielema/Papers-PDF/CCIS-WP-112-2004.pdf.

UNDP Human Development Report (2013), The Rise of the South: Human Progress in a Diverse World. New York: United Nations Development Programme. [Online] Available from: http://hdr.undp.org/sites/default/files/reports/14/ hdr2013_en_complete.pdf.

Vargas-Silva, C. (2011), Policy primer: Migration and development. The Migration Observatory. London, UK: Oxford. [Online] Available from: http://www.migrationobservatory.ox.ac.uk/sites/files/migobs/Migration\%20and\%20Development $\% 20$ Policy\%20Primer.pdf.

Wehmeier, S. (Ed.) (2000), Oxford Advanced Learner's Dictionary of Current English. Sixth Edition. Oxford University Press: Oxford, 1600 p.

WHO Regional Office for Europe (2012), Measurement of and target-setting for well-being: an initiative by the WHO Regional Office for Europe. Second meeting of the expert group Paris, France, $25-26$ June 2012. [Online] Available from: http://www.euro.who.int/_data/assets/pdf_file/0004/195511/e96732r.pdf.

World Bank (KAM 2012), KEI and KI Indexes [Online] Available from: http://info.worldbank.org/etools/kam2/KAM_ page 5.asp. 